\title{
UN EJEMPLO DE DEVOCIÓN MARIANA: EL RETABLO DE LA ERMITA DE NUESTRA SEÑORA DE LA FUENTE (BOQUEIXÓN, A CORUÑA)
}

\author{
$\mathrm{M}^{\mathrm{a}}$ DOLORES VILLAVERDE SOLAR
}

\begin{abstract}
Resumen
El santuario de $\mathrm{N}^{\mathrm{a}} \mathrm{S}^{\mathrm{a}}$ de la Fuente es de gran devoción y tiene tras de sí toda una leyenda en torno a la imagen de la Virgen. Luis Herosa es el encargado de pintar en 1786, el retablo mayor de la ermita que se divide en tres zonas destacando la imagen de María que aparece rodeada por el ciclo del Rosario (15 tondos), cuyo rezo se impone a finales del siglo XVIII.
\end{abstract}

\section{Palabras Clave}

Santuario, retablo, rosario.

\begin{abstract}
This sanctuary has a great devotion and leyend around the Virgin. In 1786 Luis Herosa, paints the altarpiece in the sanctuary. The altarpiece has been divided in three zones detaching the Virgin's statue who is been rounded about the Rosary (15 misteries), a very important pray in XVIII century.
\end{abstract}

\section{Key Words}

Sanctuary, altarpiece, rosary. 


\section{INTRODUCCIÓN}

En la orilla derecha del río Ulla, ocupando un valle, se asienta la pequeña población de San Lorenzo de Pousada que pertenece al arciprestazgo de Ribadulla, diócesis de Santiago de Compostela y al ayuntamiento de Boqueixón (A Coruña) ${ }^{1}$. En términos de la parroquia se encuentra enclavada una pequeña ermita dedicada a la Virgen del Rosario ${ }^{2}$, pero que se conoce como de Nuestra Señora de la Fuente.

Por aportaciones documentales ${ }^{3}$ sabemos que a mitad del siglo XVIII la ermita ya estaba edificada, puesto que la primera referencia escrita data de 1748: «Hermita de Nuestra Señora de la Fuente, hecha por devoción de este cura, de buena fábrica con crucero, es mui milagrosa esta soberana ymagen, hay en el marzo una procesión a la que concurren muchas parroquias con cruces y pendones.... $\rangle^{4}$.

Este estudio se centra especialmente en el análisis de las pinturas ${ }^{5}$ que cubrían el muro de cabecera de la capilla, concebidas como un homenaje a María.

En 1786 se llevan a cabo obras de reparación en el santuario "prezisos $p^{a} s u$ mejor dezencia $»^{6}$. Los reparos afectan a la fábrica del edificio, pero de igual forma se lleva a cabo la obra del retablo mayor y escaparate de Nuestra Señora: «Mas dan y se le admiten en data veinte y cinco $R^{s}$ que asimismo pagó en su vida dho cura su thio a Dn Juan de Lamas y Lossada maesttro de esculttor por el escaparate $p^{o}$ Nuestra Señora y más obra de su rettablo maior, composizión de la puertta trabiesa de la capilla y ottros reparos nezesarios de que presentaron rezivo firmado del sittado maestrto de escultor»?.

Ese mismo año, 1786, el pintor Luis Herosa se encarga de la pintura del camarín «...dan y se le admitten en datta duzientos $R^{s}$ vellon que ygualmente pagó dho

\footnotetext{
${ }^{1}$ Villaverde Solar, M. D.: El arte religioso en el arciprestazgo de Ribadulla. Tesis doctoral dirigida por el prf. Dr. D. José Manuel López Vázquez. Santiago, 1999.

${ }^{2}$ Rivas Quintas, E.: «Onomástica da Virxe María en Ourense (I)». Boletín del Seminario Fontán -Sarmiento, $\mathrm{n}^{\circ}$ 14, 1993. P. 39.

${ }^{3}$ Como base documental se consultaron los libros de Fábrica y Cofradías que se conservan en el Archivo Parroquial de Pousada y el legajo $\mathrm{n}^{\circ} 1268$ de la serie Visitas custodiado en el Archivo Histórico Diocesano de Santiago.

${ }^{4}$ A.H.D.S. Fondo general. Serie Visitas. Legajo $\mathrm{n}^{\circ} 1268 \mathrm{~s} / \mathrm{n}$.

${ }^{5}$ Se hace una visión esquemática del conjunto ya que la documentación con que se cuenta para el estudio de la pintura es muy escasa e inferior a la arquitectura y escultura, como ocurre generalmente con toda la pintura de los siglos XVII y XVIII, ver Monterrroso Montero, J. M.: «La condición social del pintor en la Galicia de los siglos XVII y XVIII». Cuadernos de Estudios Gallegos. XLII. 107 (1995) P. 372.

${ }^{6}$ A. Parroquial de Pousada: Libro Cofradía de $N^{a} S^{a}$ del Rosario: 1786-1913, folio, $7 \mathrm{r}^{0}$ y v ${ }^{0}$.

${ }^{7}$ A. Parroquial. Libro Cofr.N $\mathrm{S}^{\mathrm{a}}$ del Rosario: 1786-1913, f. $7 \mathrm{v}^{\mathrm{o}}$.
} 
cura en su vida a $D^{n}$ Luis Herosa pinttor vez de la fr ${ }^{a}$ de Santta Euxenia de Fao por aver pintado el escaparatte o camarín de Nuestra Señora en el rettablo y alttar maior de su capilla de que manifesttaron rezivo firmado de dho pinttor» ${ }^{8}$.

Durante el barroco el culto a la Madre de Dios se impone 9 . Los dominicos fueron introduciendo el culto a la Virgen del Rosario ${ }^{10} \mathrm{y}$ el rezo del mismo, que se concibe como el arma más poderosa para vencer a los enemigos de Dios y de las almas.

De igual manera el número de cofradías crece, alcanzando su punto culminante a finales del siglo XVIII, experimentando un crecimiento notable las de Ánimas, así como las de carácter mariano ${ }^{11}$. Y de esta forma, en las últimas décadas del siglo, cuando ya están presentes los enunciados neoclásicos se mantiene vivo el culto a María que se populariza durante el anterior período. La necesidad de engalanar el santuario de una manera conforme a esta advocación encuentra su razón de ser en este gran conjunto deliberadamente ubicado de manera que quien entre en el santuario medite y rece el rosario. La idea consistía en un programa iconográfico amplio con un total de quince escenas que representan los quince Misterios del Rosario ${ }^{12}$.

Las pinturas, lucirían en todo su esplendor ocupando el muro testero (Lámina 1). Pero el afán rehabilitador de los últimos años hizo que se iniciaran una serie de reformas imprescindibles para la «buena salud» de la capilla, que tuvieron como consecuencia su traslado impidiendo su contemplación en el interior de la ermita y desconozco si se efectuará la conveniente restauración de las mismas o si volverán a su tradicional ubicación.

\footnotetext{
${ }^{8}$ A. Parroquial. Libro Cofr.N $\mathrm{N}^{\mathrm{a}} \mathrm{S}^{\mathrm{a}}$ del Rosario: 1786-1913, f. $7 \mathrm{v}^{\mathrm{o}}$ y $8 \mathrm{r}^{\mathrm{o}}$.

${ }^{9}$ Precedo Lafuente, J.: «El culto mariano en Galicia». Galicia Terra Unica-Galicia Renace. Santiago, 1997. Pp. 114-125.

${ }^{10}$ González Lopo, D. L.: «Las devociones religiosas en la Edad Moderna», Galicia Terra Única, Galicia Renace. Santiago, 1997. Pp. 300-302. Y Fernández Castiñeiras, E.: «El lenguaje pictórico mariano de la capilla mayor de la catedral de Mondoñedo» Adaxe, $n^{\circ}$ 7, 1991. P. 44.

${ }^{11}$ López, R.: «El ámbito religioso gallego durante la Edad Moderna». Galicia Terra ÚnicaGalicia Renace. Santiago, 1997. P. 110. Y Barreiro Mallón, B.: «El clero en la diócesis de Santiago, estructura y comportamientos. Siglos XVI-XIX». Compostellanum XXXIII. 1988. P. 504.

${ }^{12}$ "...Y si los exemplos de el Rosario están simbolizados en la rosa, como los de la concepción en la azucena; empezando también todos los meses por los del Rosario y acabando por los de la Concepción, bien podremos dezir que aqui es donde la hallará el devoto...». Dolz de Castellar, E.: Año Virgineo. Tomo IV, 1727.
} 


\section{DESCRIPCIÓN DE LA OBRA}

Como si de un escenario se tratase, dos figuras angelicales abren el telón tras el cual contemplamos el aparatoso conjunto mural sobre tabla que presenta un esquema tripartito, el muro se «divide» en tres zonas perfectamente diferenciadas rodeando el camarín de Nuestra Señora: Sobre la cabeza de María se sitúan los Misterios Gozosos mientras los Dolorosos y Gloriosos se hallan a la derecha e izquierda respectivamente rodeando las imágenes de dos santos fundadores: San Francisco de Asís y Santo Domingo de Guzmán ${ }^{13}$. Las escenas se distribuyen en pequeños medallones ovales que son sujetados por puttis. Centra el muro de cabecera del templo el camarín de Nuestra Señora del Rosario, trazado como un edículo templario bajo el que se cobija la imagen de Nuestra Señora, flanqueado por dos de los cuatro ángeles que se mencionan en el inventario del año 1771: "Quatro ángeles de cuerpo, cada uno con su platillo que sirven $p^{a}$ adorno de la peana del altar de Nuestra Señora de la Fuente, todo ello pintado de nuevo respectivam $\left.{ }^{t e}\right\rangle^{14}$.

Los Misterios Gozosos centran su argumento en la Infancia de Jesús. Este ciclo goza de preferencia en los santuarios marianos por la lógica presencia de Nuestra Señora en é ${ }^{15}$.

1. La escena superior representa el momento de la Anunciación (Lámina 2) del ángel a María que por medio del Espíritu Santo va a concebir a Jesús: «En el mes sexto fue enviado el ángel Gabriel de parte de Dios a una ciudad de Galilea llamada Nazaret, a una virgen desposada con un varón de nombre José, de la casa de David; el nombre de la virgen era María. Y presentándose a ella, le dijo: Salve, llena de gracia, el Señor es contigo. Ella se turbó al oír estas palabras y discurría qué podría significar aquella salutación. El ángel le dijo: No temas, María, porque has hallado gracia delante de Dios y concebirás en tu seno y darás a luz un hijo, a quien pondrás por nombre Jesús». (Lucas 1, 26-31).

El anuncio del ángel a María se desarrolla en un marco arquitectónico indefinido, un interior del que únicamente podemos ver los cortinajes del fondo

${ }^{13}$ Monterroso Montero, J. M.: «La obra de Domingo Antonio de Uzal y el santuario de Nuestra Señora de la Barca de Muxía». Abrente. 1995-96. № 27-28. P. 246.

${ }^{14}$ A. Parroquial, Libro de fábrica: $1769-1859$, folio $2 \mathrm{r}^{\circ}$.

${ }^{15}$ «...Tu en el estrecho campo de tu vientre puro concebiste al que no cabe en el cielo. Tu la Madre de Aquel eres, que guio al Pueblo por el desierto, guia también, o Señora, nuestras acciones todas, para que no andemos por los caminos errados...». Dolz de Castellar, E.: Año Virgineo. Tomo IV, 1727. P. 60.

Cuadernos de Estudios Gallegos, Tomo LI, Fascículo 117, Santiago 2004. (Págs. 407 - 431) 


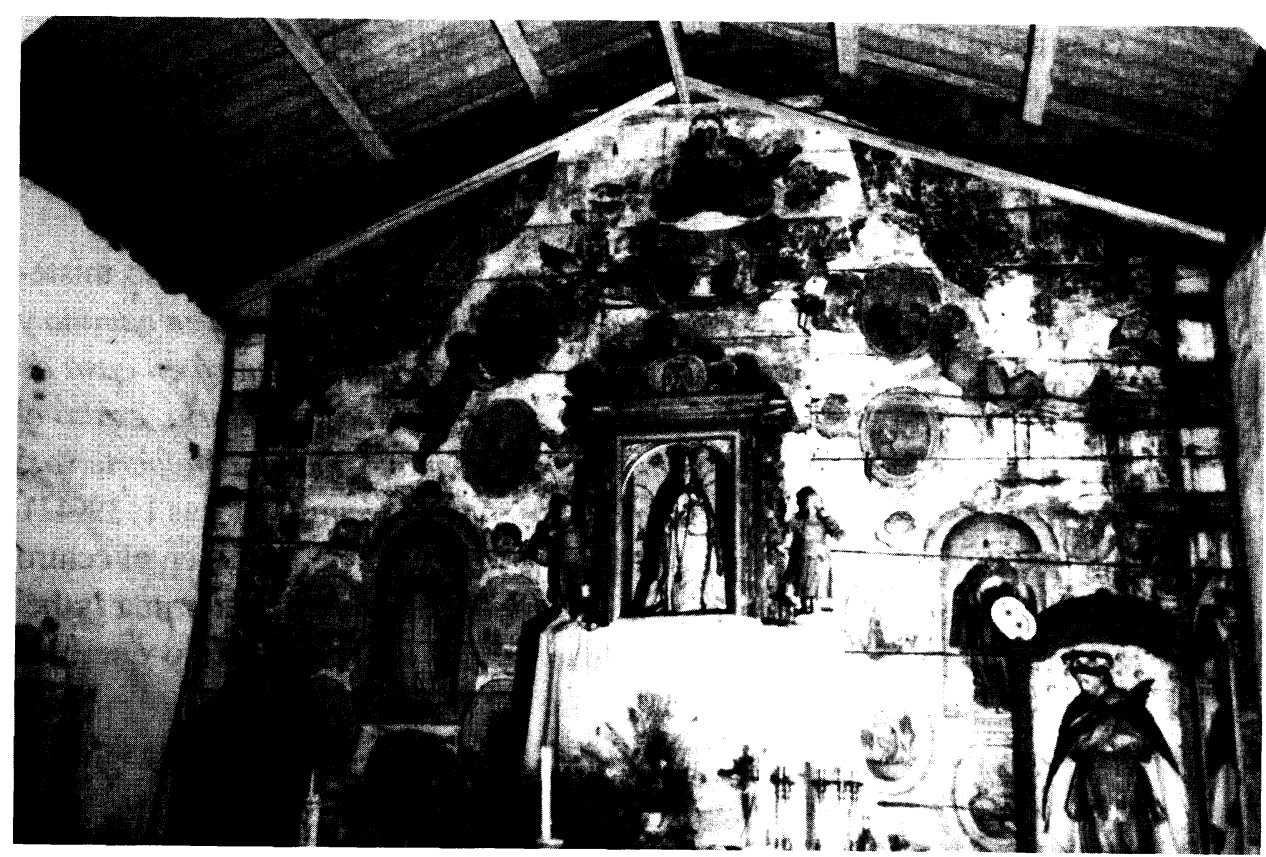

Figura 1.

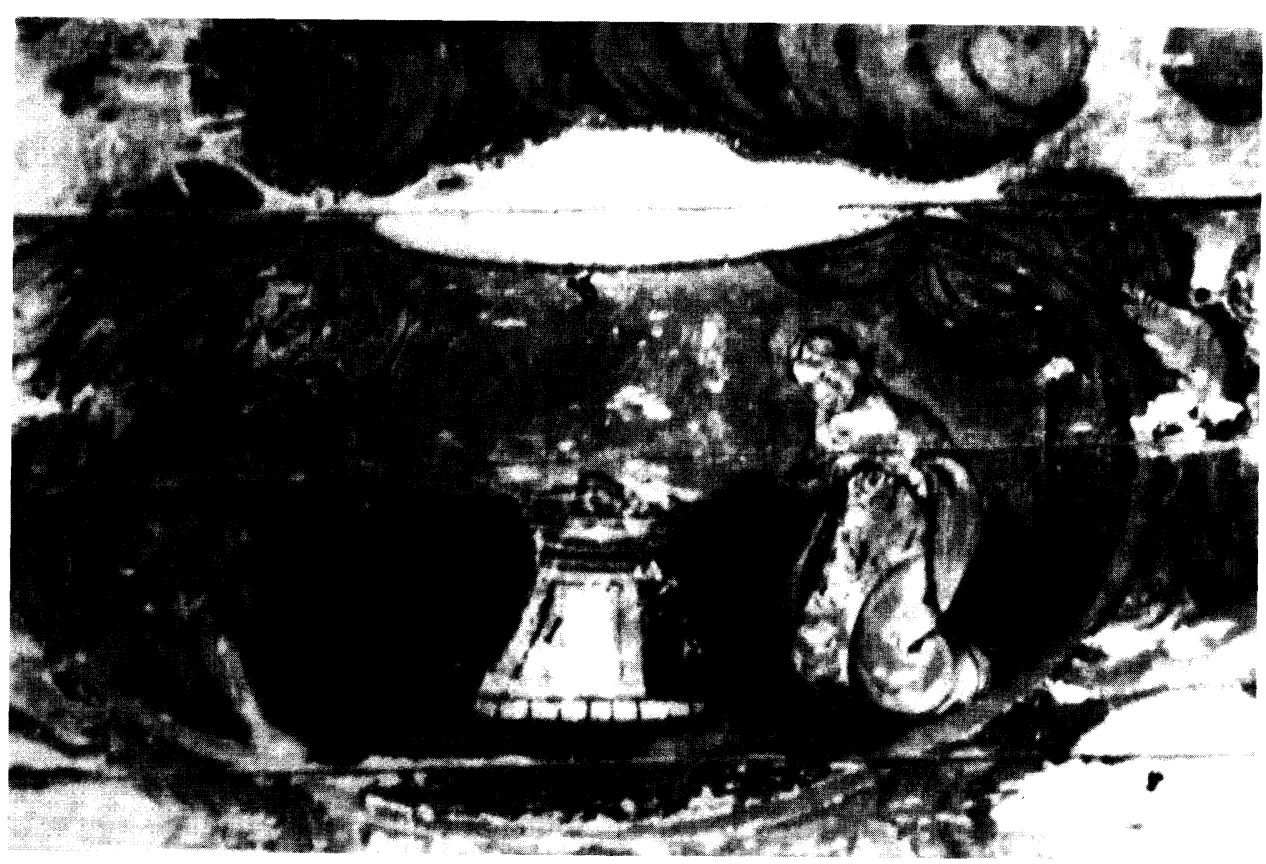

Figura 2.

Cuadernos de Estudios Gallegos, Tomo LI, Fascículo 117, Santiago 2004. (Págs. 407 - 431) 
de la estancia. El artista interpreta el episodio religioso con toda su simplicidad centrando el interés en la dulzura de rostros y gestos de los dos protagonistas. La Virgen se sitúa a la derecha vista de medio perfil, arrodillada, con actitud humilde ante el atril con un libro. El ángel, de perfil, con su mano derecha extendida señalando el cielo, de donde proviene.

2. En sentido descendente en el lado izquierdo, se muestra el segundo misterio, La Visitación (Lámina 3): «En aquellos días se puso María en camino y con presteza. Fue a la montaña, a una ciudad de Judá, y entró en casa de Zacarías y saludó a Isabel Así que oyó Isabel el saludo de María, exultó el niño en su seno, e Isabel se llenó del Espíritu Santo, y clamó con fuerte voz: ¡Bendita tú entre las mujeres y bendito el fruto de tu vientre! (Lucas 1, 39-42). En la representación del segundo Misterio, aparecen de perfil, en el centro del tondo, María en el momento de abrazar efusivamente a su prima Isabel quedando relegado a un segundo plano un personaje masculino que bien pudiera ser Zacarías, esposo de la madre del Bautista.

3. El Nacimiento (Lámina 4), se encuentra en el medallón situado a la derecha del anteriormente analizado. El primer término atrae la atención del espectador hacia María que se encuentra arrodillada ante el pesebre en el que está acostado su hijo, detrás, José la mira en actitud paternal. El buey y el asno se hallan también, con una distribución que parece la espontánea y natural que narra el evangelio de Lucas: «...José subió de Galilea, de la ciudad de Nazaret, a Judea, a la ciudad de David, que se llama Belén, por ser él de la casa y de la familia de David, para empadronarse con María, su esposa, que estaba encinta. Estando allí, se cumplieron los días de su parto y dio a luz a su hijo primogénito, y le envolvió en pañales y le acostó en un pesebre, por no haber sitio para ellos en el mesón». (Lucas, 2, 4-7).

4. Bajo el tondo de la Visitación, se puede contemplar el cuarto de los misterios: La Purificación (Lámina 5), o presentación de Jesús en el templo a los cuarenta días de su nacimiento conforme a la Ley de Moisés: "Había en Jerusalén un hombre llamado Simeón, justo y piadoso, que esperaba la consolación de Israel, y el espiritu Santo estaba en él. Le había sido revelado por el espíritu Santo que no vería la muerte antes de ver al Cristo del Señor. Movido del Espíritu, vino al templo, y al entrar los padres con el niño Jesús para cumplir lo que prescribe la Ley sobre El, Simeón le tomó en brazos...». (Lucas 2, 25-28). Este momento es el representado en el medallón de manera que Simeón queda a la izquierda con el Niño en brazos mientras José y María aparecen a la derecha. La Virgen se arrodilla simbolizando con este gesto su purificación. 


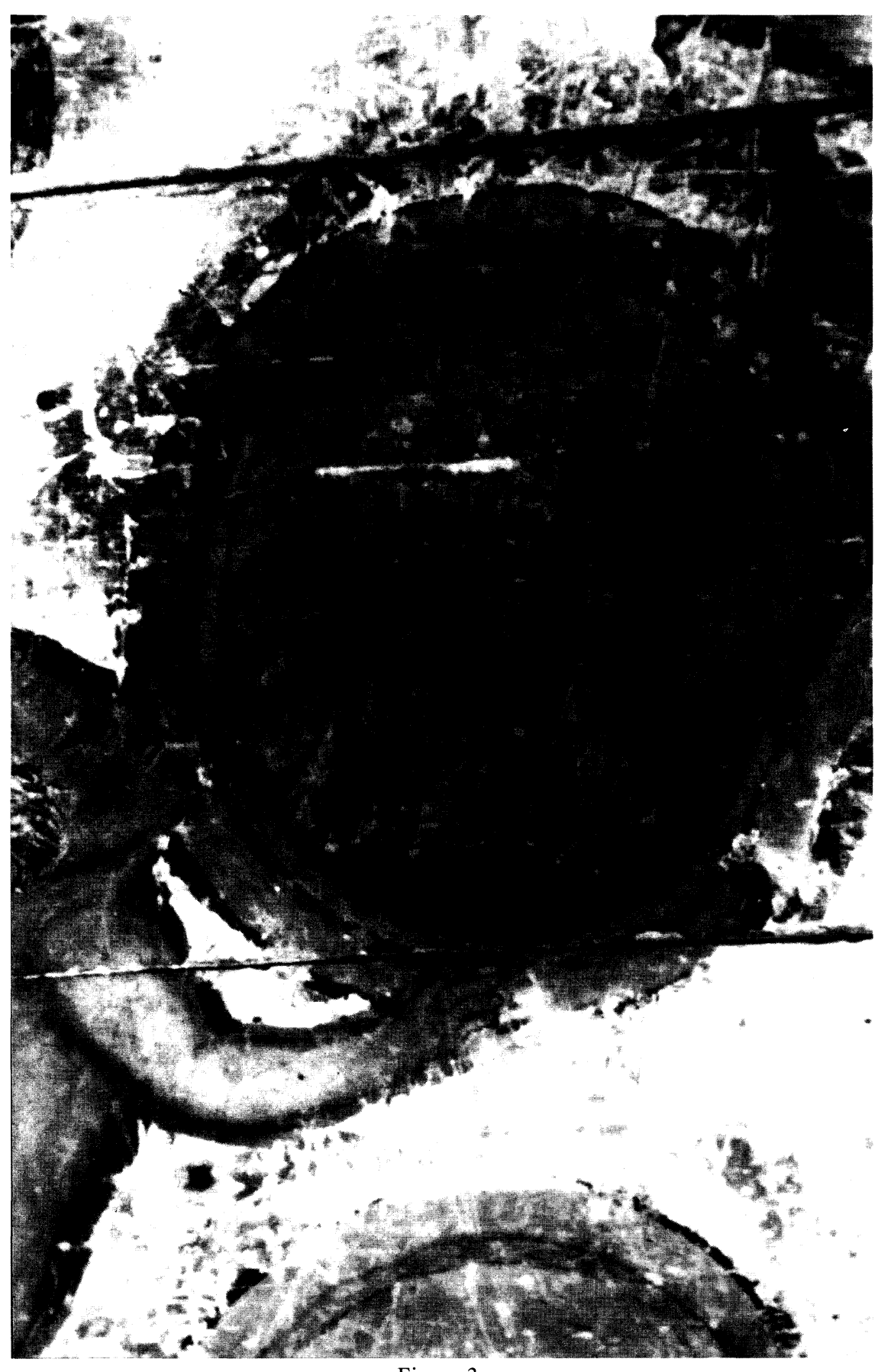

Figura 3.

Cuadernos de Estudios Gallegos, Tomo LI, Fascículo 117, Santiago 2004. (Págs. 407 - 431) 


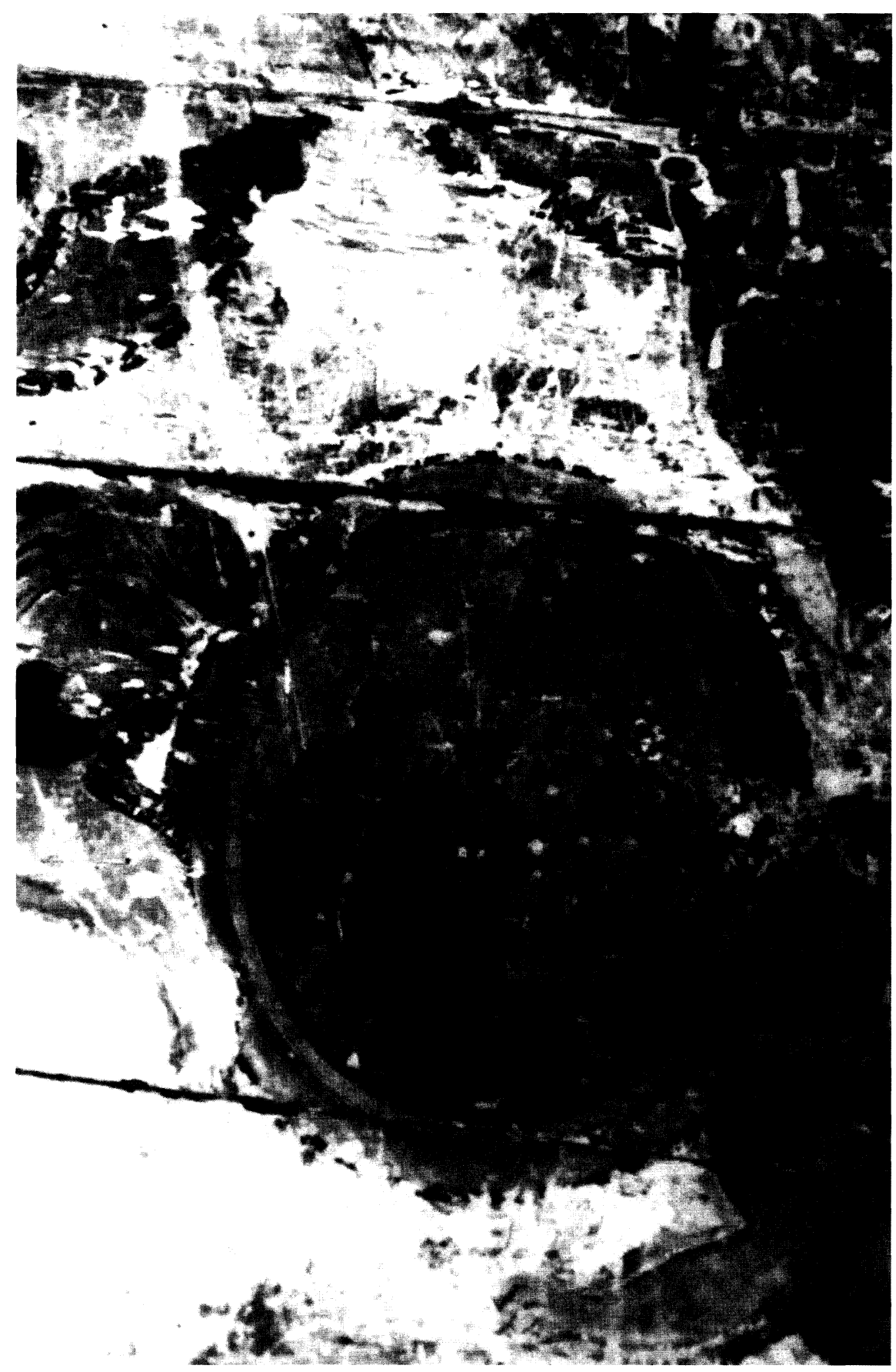

Figura 4. 


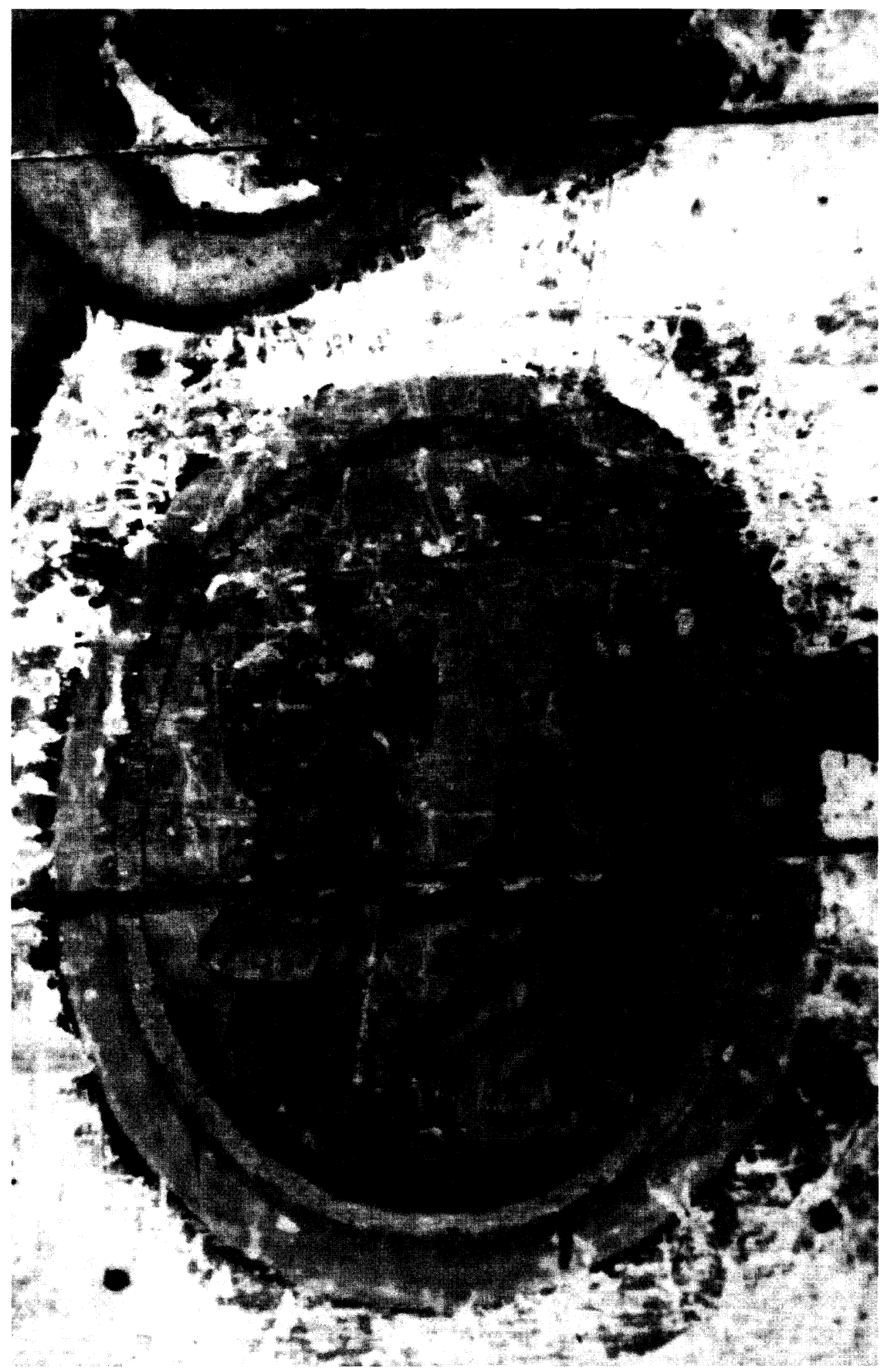

Figura 5.

Cuadernos de Estudios Gallegos, Tomo LI, Fascículo 117, Santiago 2004. (Págs. 407 - 431) 
5. El Niño perdido y hallado en el Templo (Lámina 6) es el último de los misterios de gozo. Vemos el momento en que José y María encuentran a Jesús después de tres días en el templo sentado entre los doctores «Cuando sus padres le vieron, quedaron sorprendidos, y le dijo su madre: Hijo, ¿por qué has obrado así con nosotros? Mira que tu padre y yo, apenados, andábamos buscándote. Y Él les dijo: ¿Por qué me buscabais? ¿No sabiais que es preciso que me ocupe de las cosas de mi Padre? (Lucas 2, 48-49).

La figura del Salvador, a la derecha, descansa sobre un trono de nubes, detalle utilizado para indicar que Jesucristo tiene su trono sobre el cielo. Llama la atención sin embargo, la omisión de los doctores, parte esencial de este episodio de la infancia de Jesús.

Para una narración lógica del rezo del rosario, debemos continuar con los Misterios Dolorosos cuya temática es la Pasión de Cristo ${ }^{16}$. Se ordenan en torno a la imagen de San Francisco (Lámina 7), cobijado bajo una hornacina de medio punto con su iconografía tradicional: el hábito de color castaño con capa sobre los hombros, amplia tonsura y un crucifijo en la mano izquierda.

1. La narración de la Pasión y Muerte de Jesús se inicia con La Oración en el huerto $^{17}$ (Lámina 8) que sigue fielmente el relato de Lucas con Jesús de rodillas, con las manos entrelazadas orando ${ }^{18}$ mientras mira al cielo donde aparece el ángel que lo conforta. A los pies de Cristo se puede ver a los tres discípulos dormidos -Pedro, Santiago y Juan-: «Saliendo, se fue, según costumbre, al monte de los Olivos, y le siguieron también sus discípulos. Llegado allí, dijoles: Orad para que no entréis en tentación. Se apartó de ellos como un tiro de piedra y puesto de rodillas, oraba, diciendo: Padre, si quieres, aparta de mi este cáliz; pero no se haga mi voluntad, sino la tuya. Se le apareció un ángel del cielo que le confortaba. Lleno de angustia, oraba con más instancia y sudó como gruesas gotas de sangre, que corrian hasta la tierra. Levantándose de la oración, vino a los discípulos y encontrándolos adormilados por la tristeza, les dijo: ¿Por qué dormís? Levantaos y orad para que no entréis en tentación». (Lucas 22, 39-46).

\footnotetext{
${ }^{16}$ Díaz Fernández, J. M.: «Liturgia,devoción y representación de Jesucristo». Galicia Terra Unica-Galicia Renace. Santiago, 1997. Pp. 171-182.

${ }^{17}$ González García, M. A.: «Vida y Pasión de Cristo en el arte gallego renacentista y barroco». Galicia Terra Unica-Galicia Renace. Santiago, 1997. Pp. 184-185.

${ }^{18}$ Monterroso Montero, J. M.: «La pintura de los siglos XVII-XVIII» en La catedral de Ourense. Editorial Xuntanza. Laracha, 1993. P. 448.
}

Cuadernos de Estudios Gallegos, Tomo LI, Fascículo 117, Santiago 2004. (Págs. 407 - 431) 


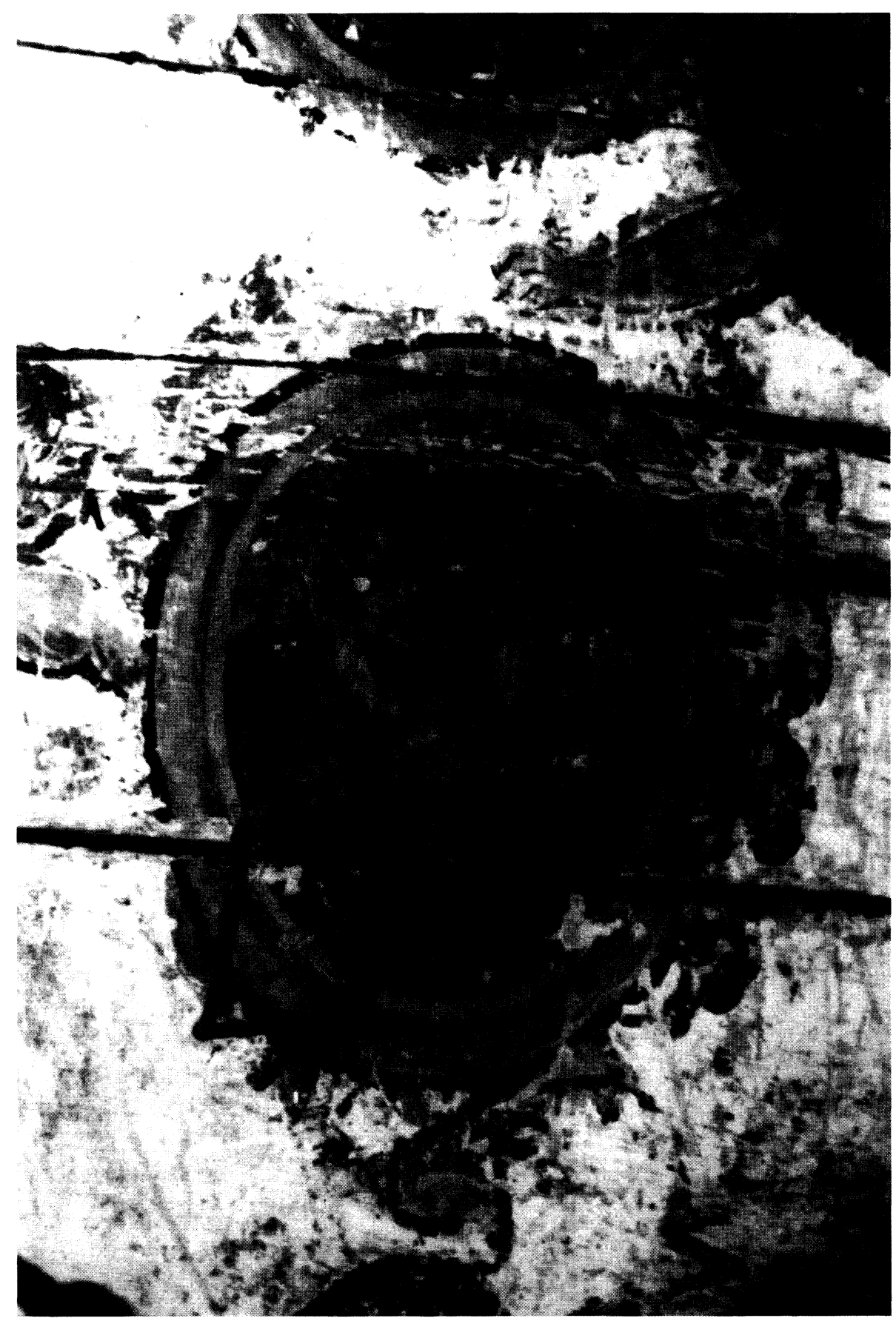

Figura 6.

Cuadernos de Estudios Gallegos, Tomo LI, Fascículo 117, Santiago 2004. (Págs. 407 - 431 ) 


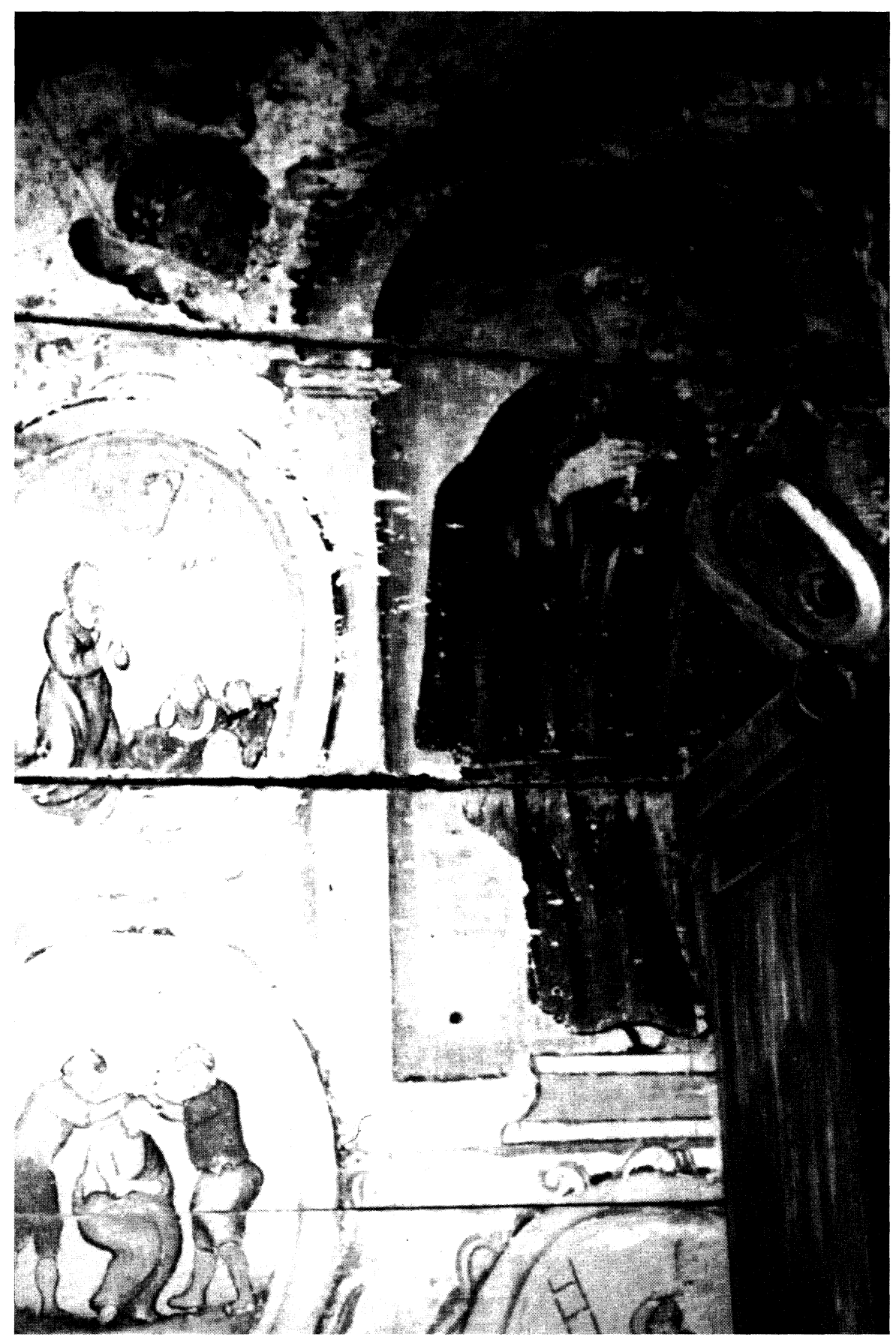

Figura 7.

Cuadernos de Estudios Gallegos, Tomo LI, Fascículo 117, Santiago 2004. (Págs. 407 - 431) 


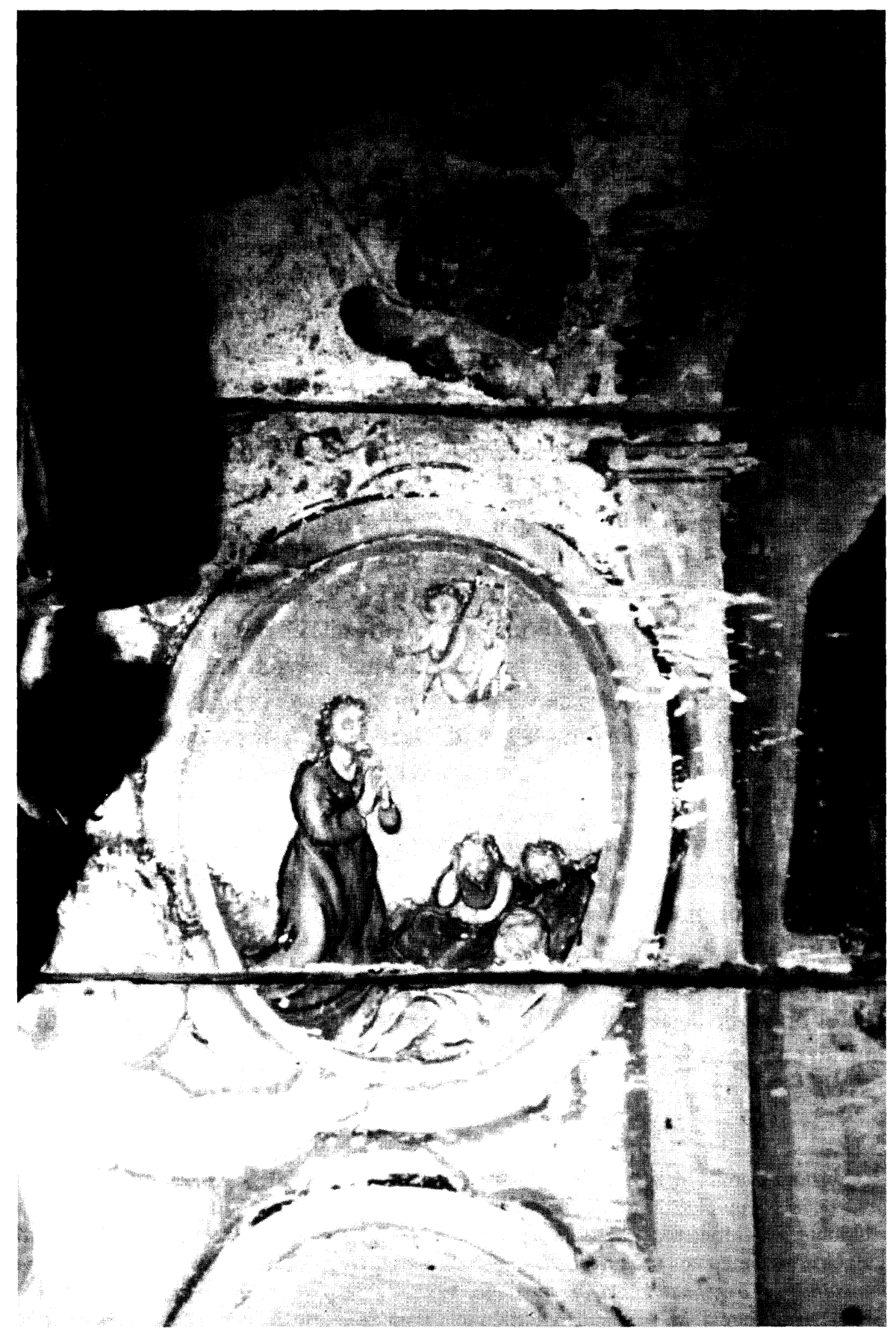

Figura 8.

Cuadernos de Estudios Gallegos, Tomo LI, Fascículo 117, Santiago 2004. (Págs. 407 - 431) 
2. Coronación de espinas ${ }^{19}$ (Lámina 9): Tras el juicio y los azotes a Jesús le visten de una ropa púrpura vieja coronándole de espinas. La escena se sitúa entre la Flagelación y su presentación al pueblo por Poncio Pilato. Es el momento de los escarnios que se hacen a Cristo por parte de los esbirros: «Entonces los soldados del gobernador, tomando a Jesús, lo condujeron al pretorio, $y$, reuniendo en torno a él a toda la cohorte, y despojándole de sus vestiduras, le echaron encima una clámide de púrpura, $y$, tejiendo una corona de espinas, se la pusieron sobre la cabeza, y en la mano una caña; y doblando ante Él la rodilla, se burlaban diciendo: ¡Salve, Rey de los judios! Y escupiéndole, tomaban la caña y le herían con ella en la cabeza. (Mateo 27, 27-30).

En un lugar indeterminado, Jesús se encuentra sentado en el instante en que los dos esbirros colocan sobre su cabeza la corona de espinas, con el torso desnudo, vestido únicamente con la túnica de color púrpura. Llama la atención el contraste entre la violencia de los soldados al golpear la cabeza de Jesús y la figura de este que parece abatirse mientras su cuerpo adquiere una forma ondulante ${ }^{20}$.

3. Muerte de Jesús en la $\mathrm{cruz}^{21}$ (Lámina 10). A los pies de la imagen de San Francisco encontramos la crucifixión, tema que centra la Pasión de Cristo, si bien aquí no se representa con la tradicional imagen del «crucificado» sino en el instante en que es clavado a los maderos, recordando las palabras que el profeta David puso en labios de Jesús sobre su propia muerte: «...han taladrado mis manos y mis pies y puedo contar todos mis huesos». (Sal 22. 17-18).

"Cuando llegaron al lugar llamado Calvario, le crucificaron alli, y a los dos malhechores, uno a la derecha y otro a la izquierda. Jesús decía: Padre, perdónalos, porque no saben lo que hacen». (Lucas 23, 33-34).

De nuevo llama la atención el contraste entre el guardián que golpea bruscamente el brazo de Jesús sobre el tablero, frente al rostro resignado de Cristo que asume su entrega a la voluntad del Padre sin rastros de violencia ni agonía.

\footnotetext{
${ }^{19}$ González García, M. A.: «Vida y Pasión de Cristo en el arte gallego renacentista y barroco» en Galicia Terra Unica-Galicia Renace, Santiago, 1997. Pp. 187-188.

${ }^{20}$ Monterroso Montero, J. M.: «Pinturas murais e restauración: Aproximación histórico-artística a algúns dos conxuntos restaurados nos últimos anos», Os profesionais da historia ante o patrimonio cultural: Liñas metodolóxicas, Santiago, 1995. P. 221.

${ }^{21}$ González García, M. A.: «Vida y Pasión de Cristo en el arte gallego renacentista y barroco». Galicia Terra Unica-Galicia Renace. Santiago, 1997. P. 190.
} 


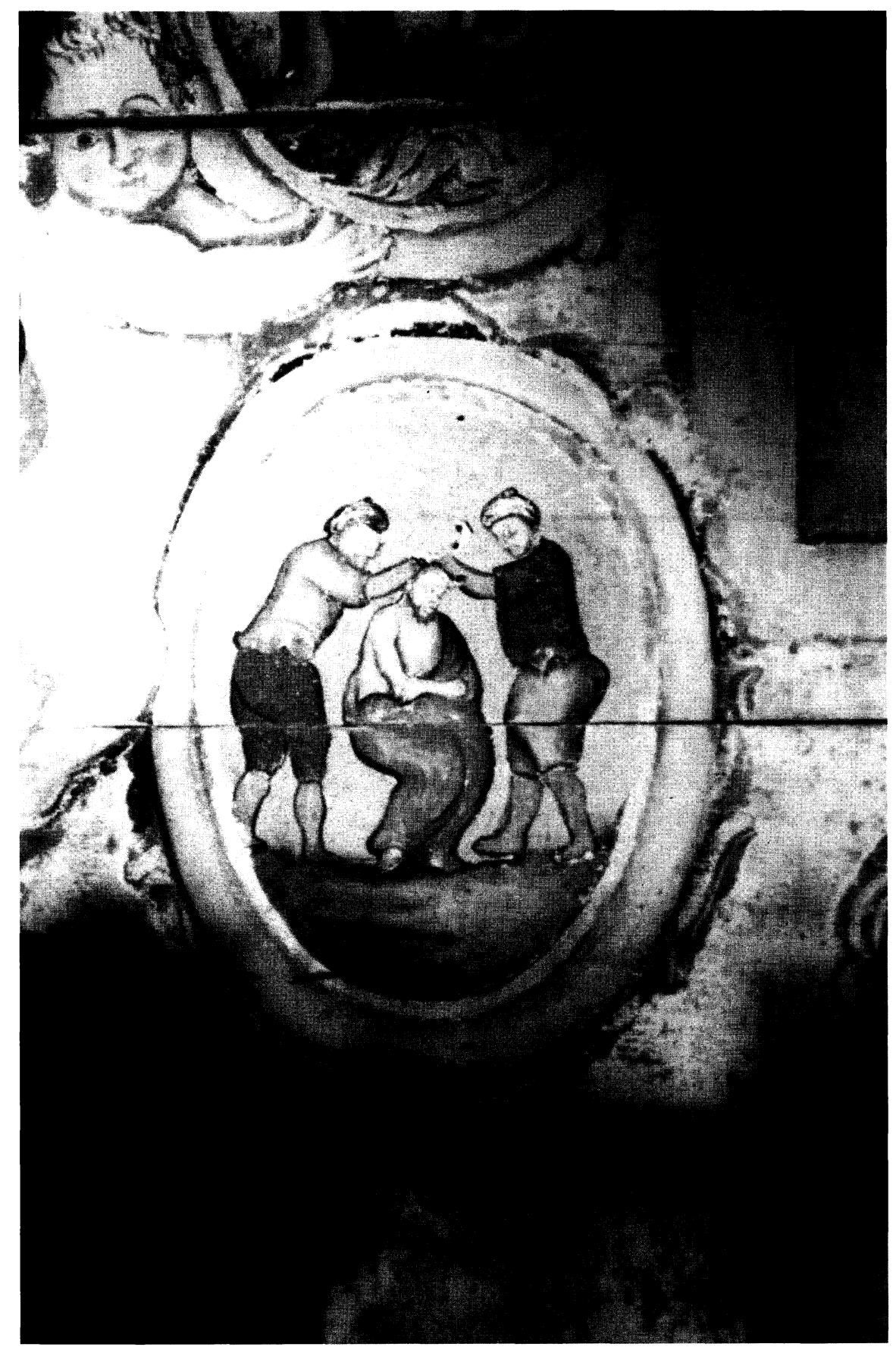

Figura 9.

Cuadernos de Estudios Gallegos, Tomo LI, Fascículo 117, Santiago 2004. (Págs. 407 - 431) 


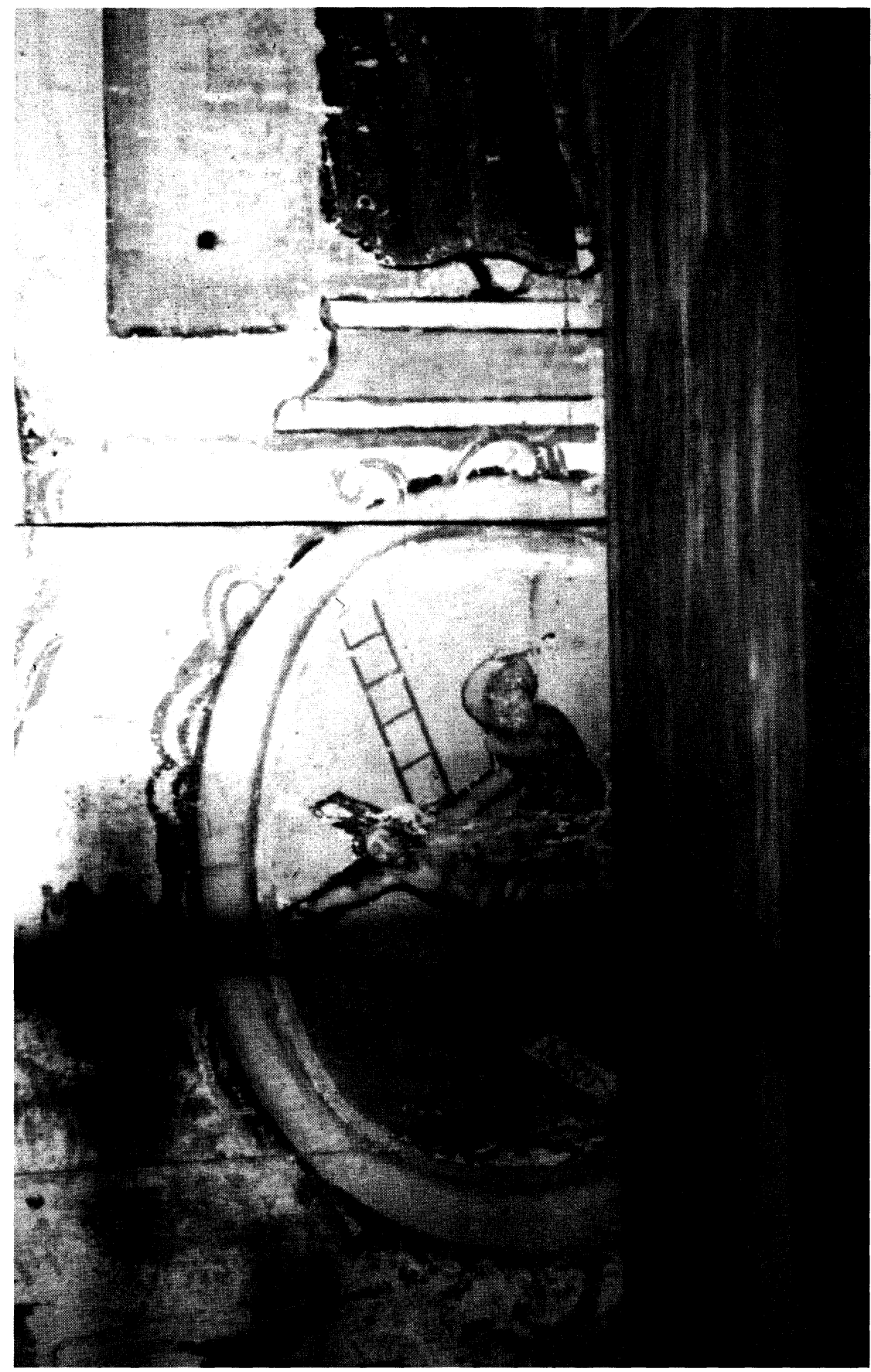

Figura 10.

Cuadernos de Estudios Gallegos, Tomo LI, Fascículo 117, Santiago 2004. (Págs. 407 - 431) 
No podemos llevar a cabo el estudio de los dos misterios que completan el ciclo de la Pasión y Muerte de Jesús (Los azotes atado a la columna y Jesús con la cruz a cuestas) por hallarse ocultos tras el camarín con la imagen de Santa Lucía.

Vinculado al misterio de la cruz está el misterio de la Resurrección, el rezo del Santo Rosario se completa con los Misterios Gloriosos, que en el santuario ocupan el espacio situado a la izquierda del camarín de la Virgen, rodeando la efigie de Santo Domingo de Guzmán (Lámina 11), que al igual que San Francisco aparece bajo una hornacina semicircular, vestido con el hábito blanco y manto con capuchón negro. Lleva el rosario en la mano izquierda y apoya la derecha en el bordón.

1. La Resurrección del Señor (Lámina 12) ocupa el primer medallón. En el primer Misterio, Cristo triunfa sobre la muerte, resucita bañado en luz, como emergiendo del sepulcro con su cuerpo todavía cubierto por la mortaja para cumplir las palabras que había dicho estando en Galilea «que el Hijo del hombre habia de ser entregado en poder de pecadores, y ser crucificado, $y$ resucitar al tercer día». (Lucas 24,7).

El pintor divide la escena en dos partes que se diferencian por la luz dorada que lo envuelve (Cielo) y el azulado de la zona inferior (Tierra).

2. Después de aparecerse vivo a los apóstoles tras la Pasión, el Señor «los llevó hasta cerca de Betania, y levantando sus manos, les bendijo, y mientras los bendecía se alejaba de ellos y era llevado al cielo. Ellos se postraron ante Él y se volvieron a Jerusalén con grande gozo». (Lucas 24, 50-53).

La Ascensión de Jesús a los cielos (Lámina 13) refleja el instante en que el cuerpo transfigurado de Jesucristo se eleva con majestuosa serenidad flotando sobre la escena mientras los discípulos quedan confundidos ante la visión.

3. La venida del Espíritu Santo (Lámina 14) nos presenta a los apóstoles reunidos el día de Pentecostés con el Espíritu Santo encima de sus cabezas en forma de lenguas de fuego centrando la escena la imagen de Pedro, siguiendo el relato de los Hechos de los Apóstoles:

"Al cumplirse el día de Pentecostés, estando todos juntos en un lugar, se produjo de repente un ruido proveniente del cielo como el de un viento que sopla impetuosamente, que invadió toda la casa en que residian. Aparecieron, como divididas, lenguas de fuego, que se posaron sobre cada uno de ellos, quedando todos llenos del espíritu Santo...». (Hechos 2, 1-4). 


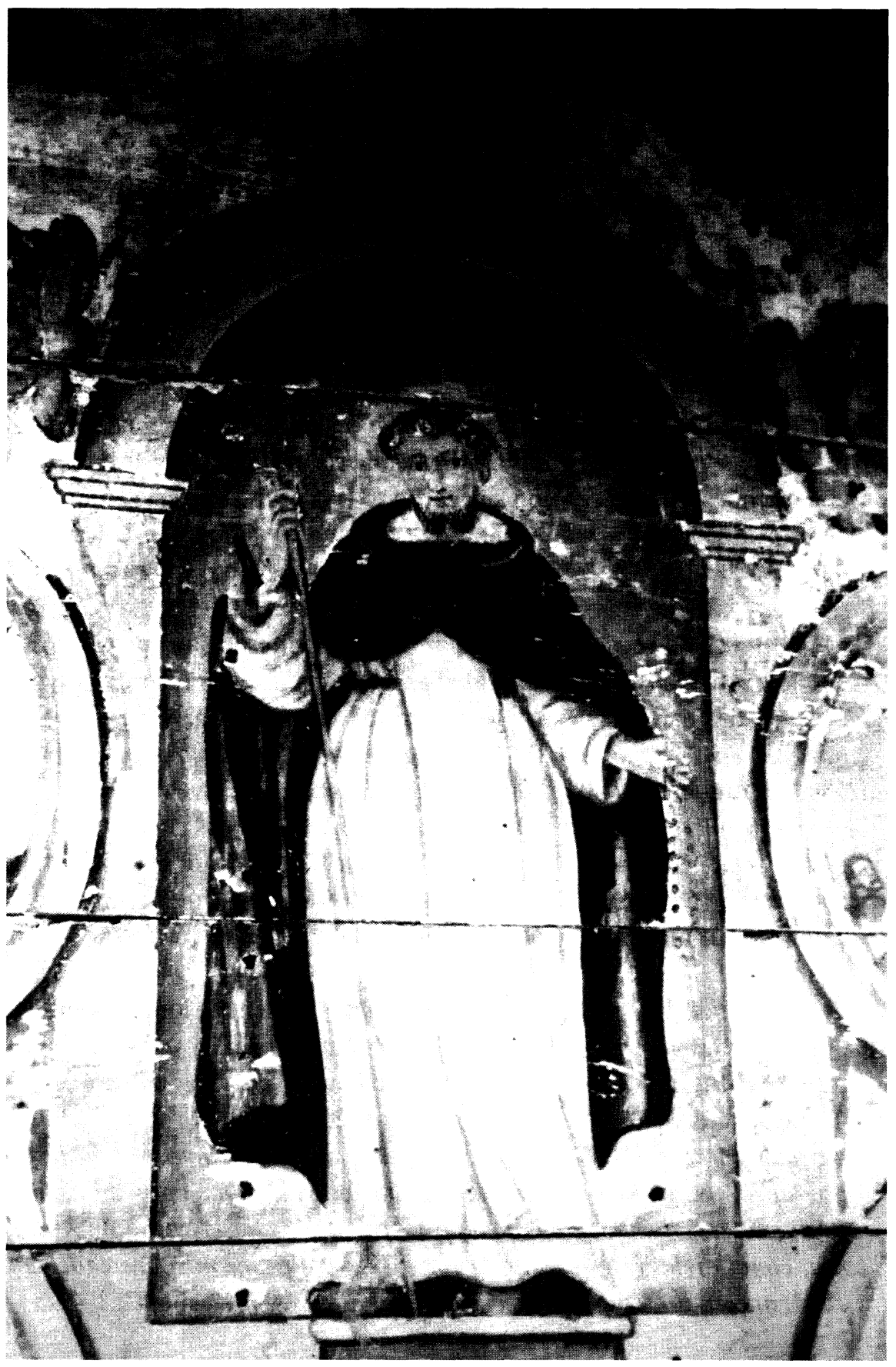

Figura 11.

Cuadernos de Estudios Gallegos, Tomo LI, Fascículo 117, Santiago 2004. (Págs. 407 - 431) 


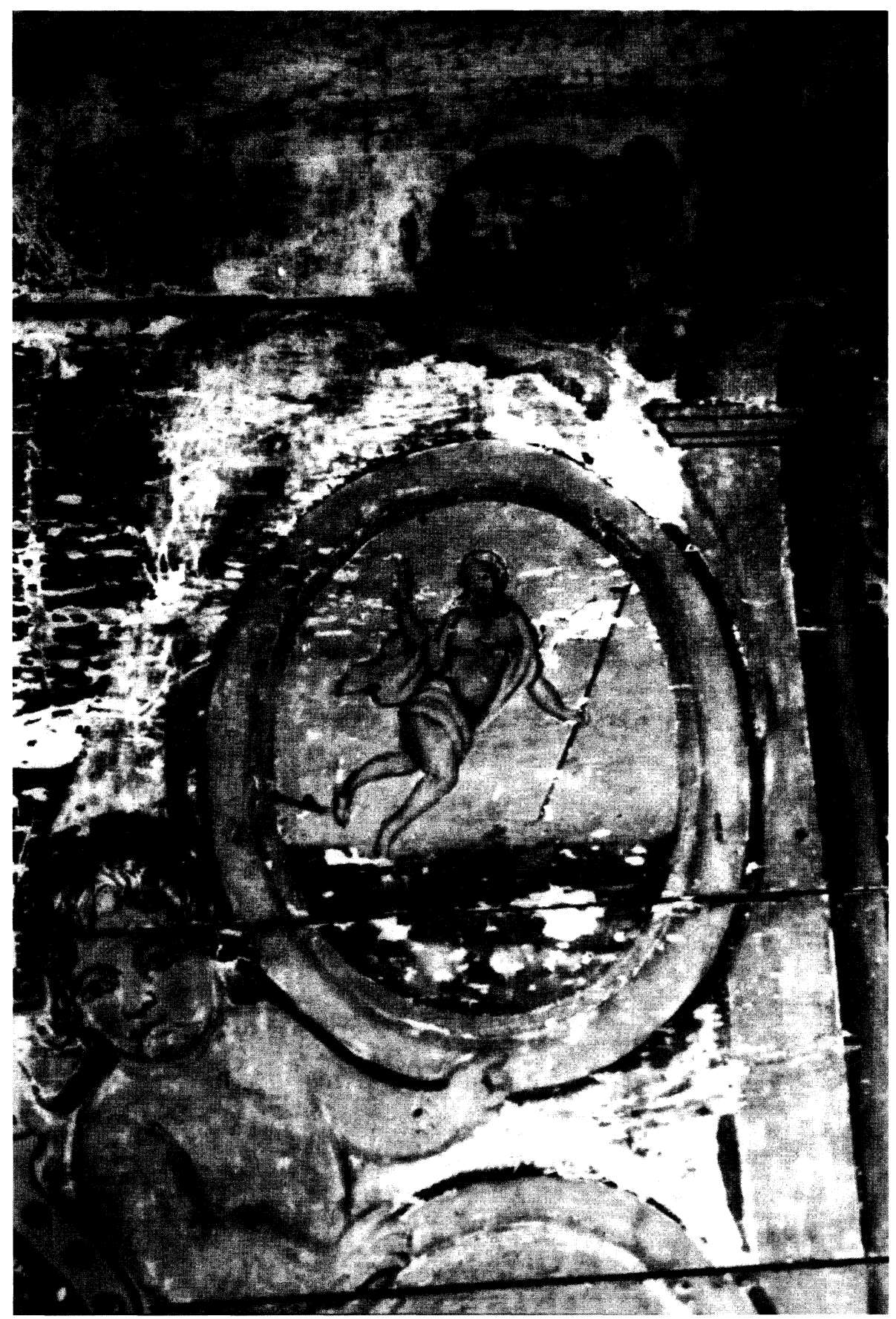

Figura 12 


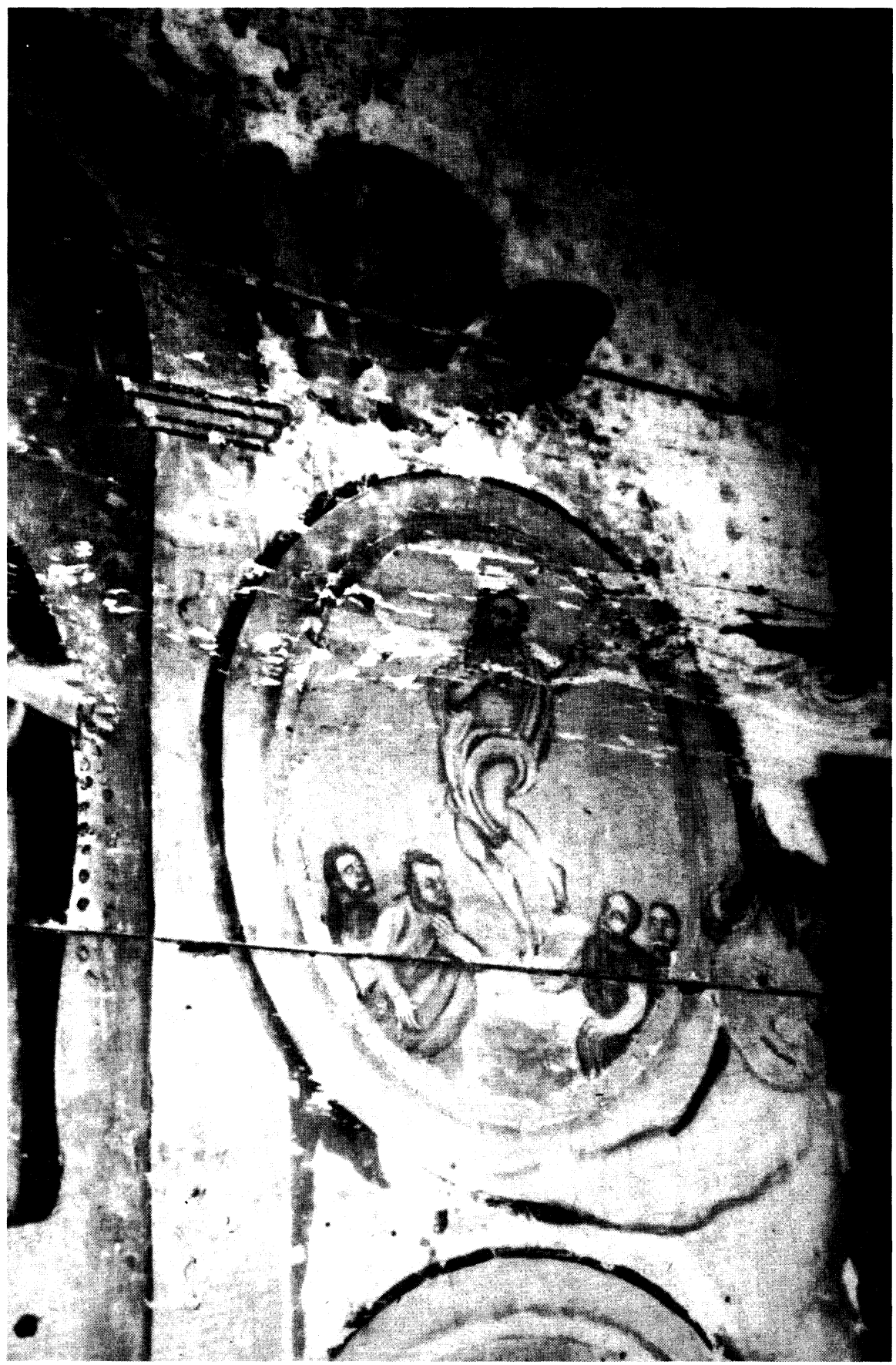

Figura 13. 


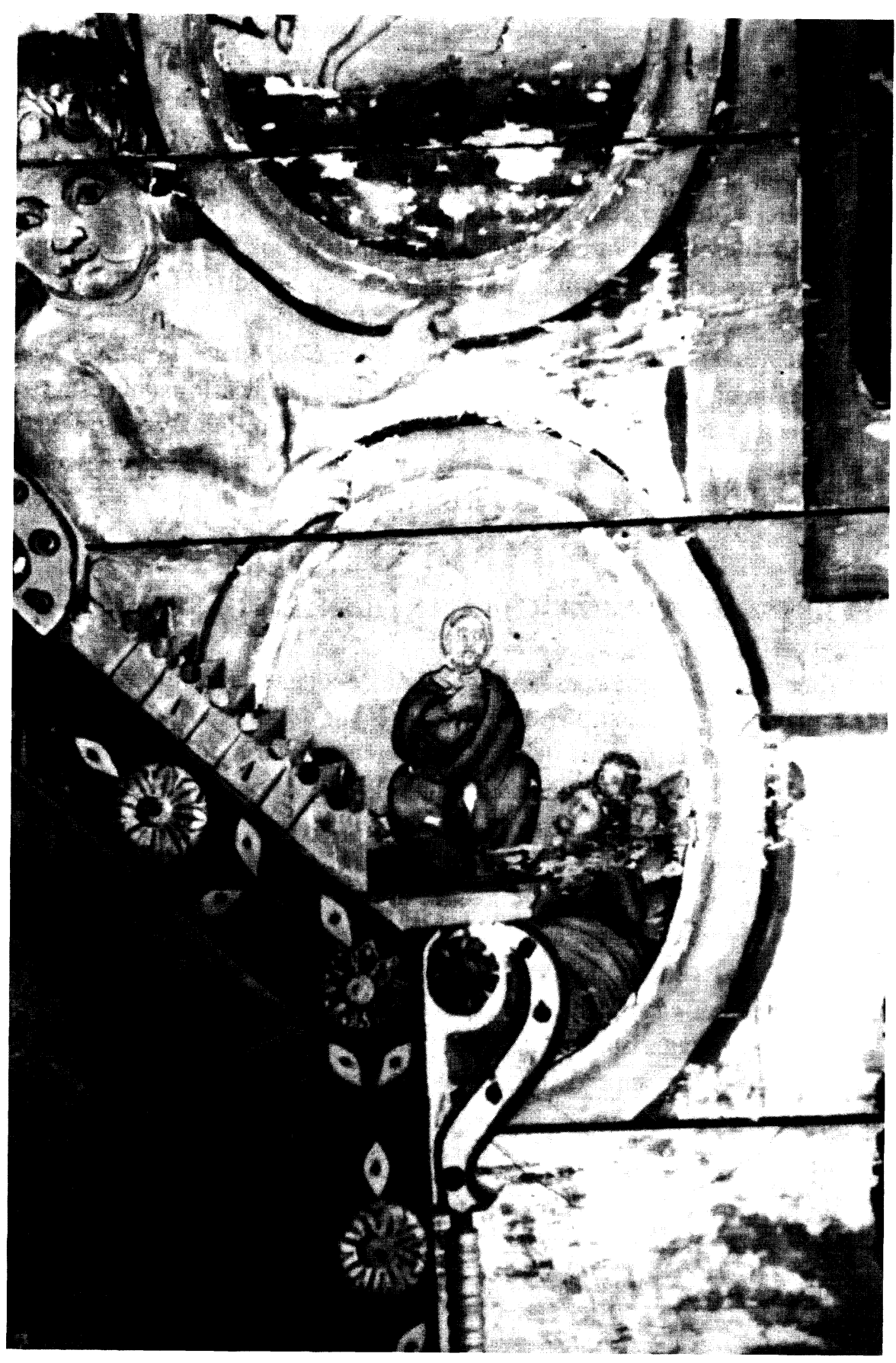

Figura 14. 
Los dos últimos misterios del Rosario celebran el destino final de la historia de María y de como cumplió Dios en ella sus promesas ${ }^{22}$ :

4. El siguiente de los tondos se ocupa con la Asunción (Lámina 15) de María a los Cielos. Por fin la Virgen Inmaculada termina el discurso de su vida terrena y es asunta en cuerpo y alma a la Gloria. Divide la escena en dos partes, la parte terrestre azulada con María sentada, extendiendo los brazos que está siendo literalmente «empujada» al cielo por dos ángeles mientras dos querubines en lo alto contemplan la escena, en dorado.

5. A los pies de Santo Domingo se encuentra la Coronación de María Santísima (Lámina 16) que completa el ciclo del Rosario. María asunta está siendo coronada por el Hijo resucitado y Dios Padre como Reina y Señora de toda la creación recordando a su Hijo. La simplicidad con que representa el momento no aminora la solemnidad del mismo.

\section{FUENTES ICONOGRÁFICAS Y ANÁLISIS ESTILÍSTICO}

Las fuentes iconográficas están perfectamente identificadas. Se trata de textos Neotestamentarios (los cuatro Evangelios y Hechos de los Apóstoles), si bien hay episodios, como el de la Asunción o Coronación de María que no tienen rúbrica evangélica pero se incorporan a los programas iconográficos dedicados a la exaltación de María.

El pintor busca la orgánica distribución de las figuras, el contraste de colores y la claridad de composición. Su propósito fue reconstruir las escenas bíblicas tan fielmente como resultara posible recuperando de este modo la tradicional finalidad didáctica del arte a través de un discurso que se distingue por su gran sencillez consiguiendo la correspondencia entre un episodio y el siguiente.

Tiende a la esquematización, claridad, y simplificación ornamental ${ }^{23}$. Falta toda indicación de lugar, la superficie es plana sin complicados escorzos y los fondos son simples manchas sobre los que se disponen las figuras en las que el dibujo desaparece ante el cromatismo. Los personajes, sin una profunda caracterización de los rostros consiguen un acusado aspecto curvilíneo contorneando los perfiles.

\footnotetext{
${ }^{22}$ Limia Gardón, F. J.: «El culto mariano en el arte», Galicia Terra Única, Galicia Renace. Santiago, 1997. P. 133.

${ }^{23}$ López Vázquez, J. M.: «El Neoclasicismo y el siglo XIX». Enciclopedia Temática de Galicia. Nauta, Barcelona, 1988. P. 129.
}

Cuadernos de Estudios Gallegos, Tomo LI, Fascículo 117, Santiago 2004. (Págs. 407 - 431) 


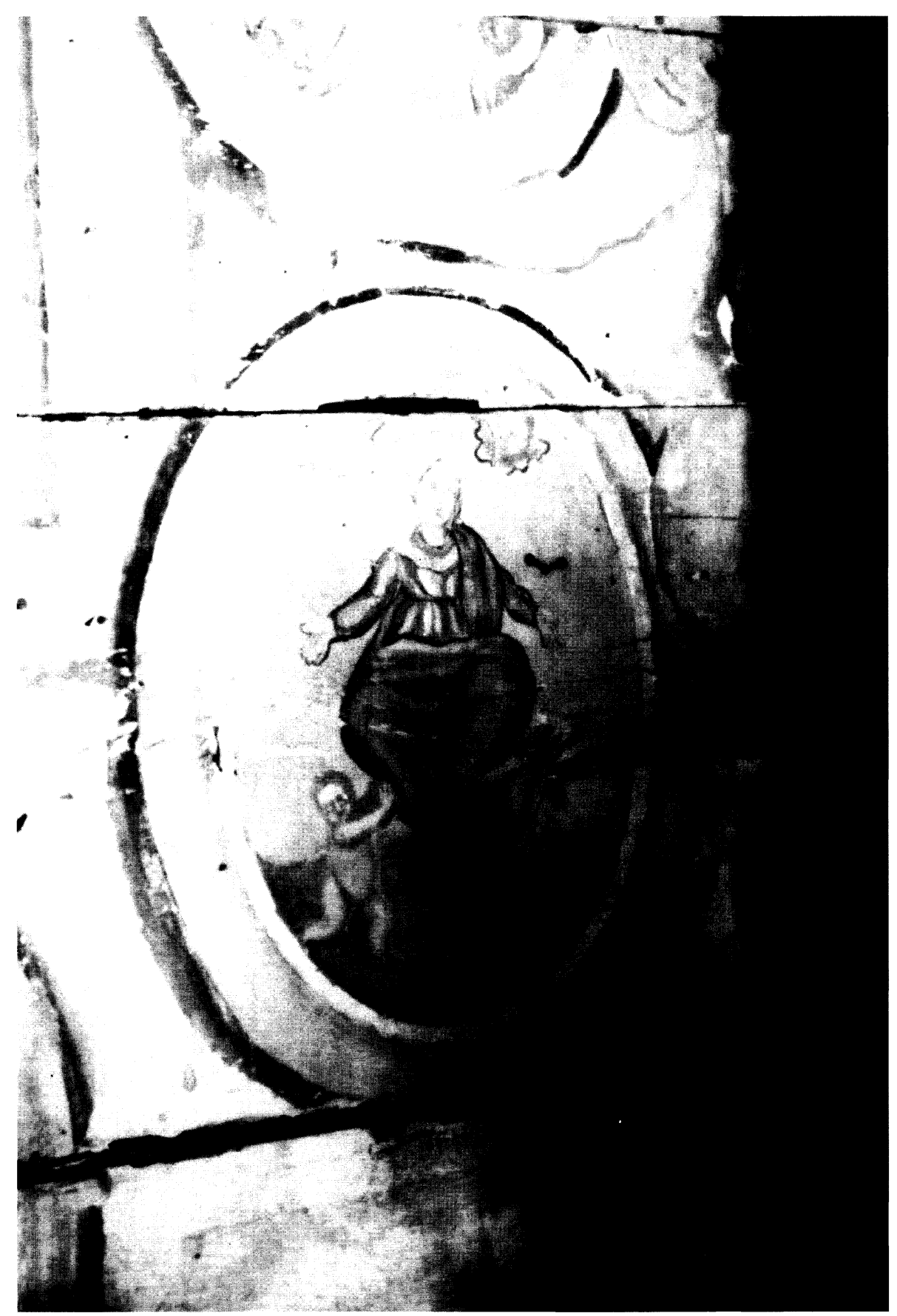

Figura 15.

Cuadernos de Estudios Gallegos, Tomo LI, Fascículo 117, Santiago 2004. (Págs. 407 - 431) 


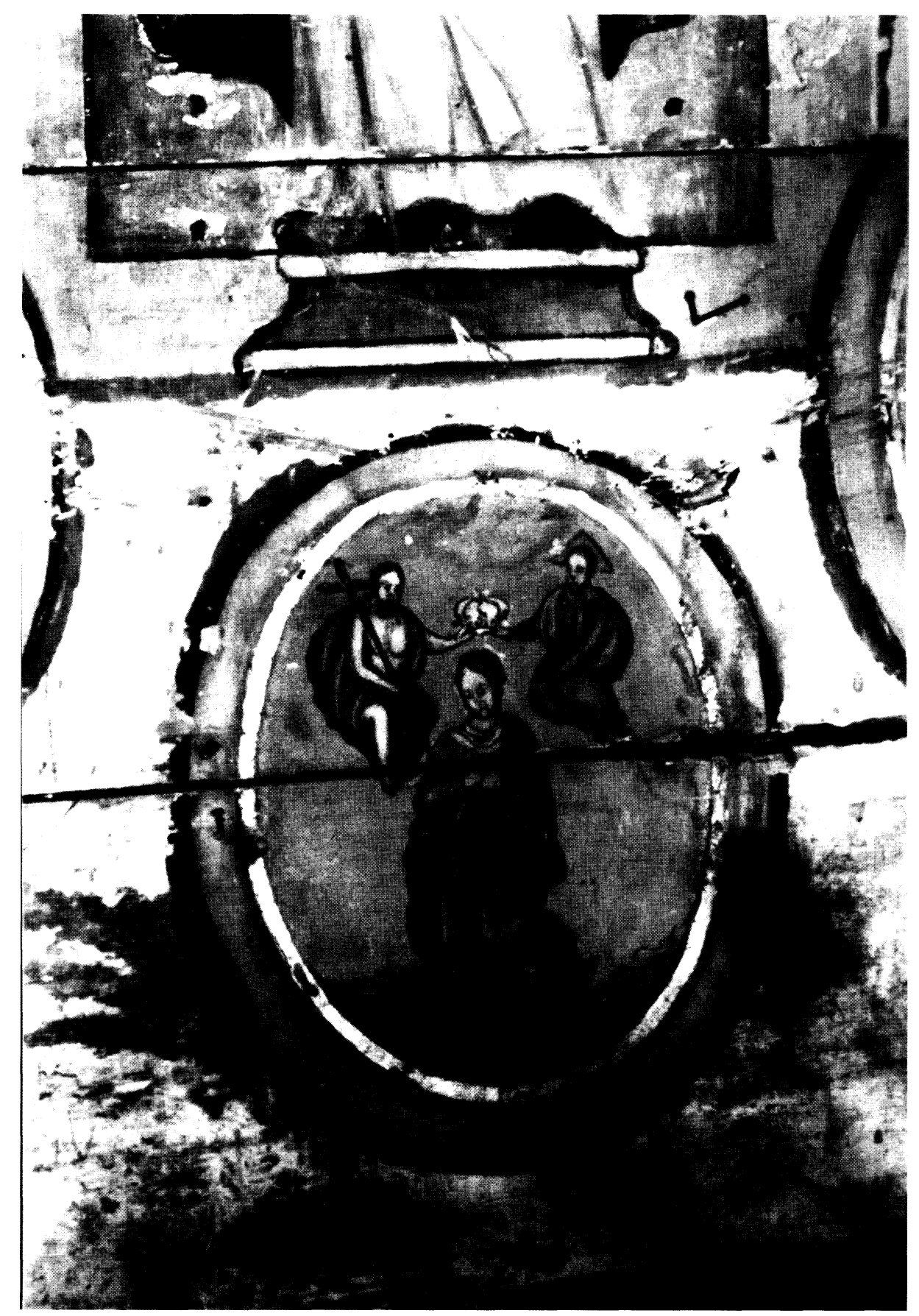

Figura 16.

Cuadernos de Estudios Gallegos, Tomo LI, Fascículo 117, Santiago 2004. (Págs. 407 - 431) 
Consigue marcar la profundidad de plano trayendo al primer término los personajes principales de cada escena.

Son significativas las características estilísticas de los iconos de los dos santos (San Francisco y Santo Domingo), que a través de sus perfiles redondeados, silueta en S, composición piramidal y la presencia de la pierna exonerada nos acercan a recetas de la imaginería de los años finales del siglo XVIII ${ }^{24}$ y en concreto a las efigies de los dos ángeles trompeteros que escoltan el camarín, realizados en 1771.

Por último, cabe destacar la gama cromática que se reduce a rojos, azules y oros que actúan como fondo para las representaciones acordes con los modelos bizantino y gótico excluyendo la profundidad espacial.

${ }^{24}$ Fernández Castiñeiras, E.: «La imaginería». Galicia Terra Unica-Galicia Renace. Santiago, 1997. P. 121.

Cuadernos de Estudios Gallegos, Tomo LI, Fascículo 117, Santiago 2004. (Págs. 407 - 431) 